\title{
Constitutional Dialogues Between Courts and LEgislatures: CAN We Talk?
}

\author{
The Honourable Chief Justice Catherine A. Fraser
}

\section{INTRODUCTION}

The topic we have been asked to address is Courts on Legislatures. ${ }^{1}$ This raises the issue about the nature of the relationship between courts and legislatures in a constitutional democracy (and for my purposes, I treat the executive and legislative branches as one). The relationship between courts and legislatures is complex and challenging. However, it need not be controversial and conflicted as long as each understands and respects the institutional role played by the other - and the dividing line between them.

The relationship between courts and legislatures is often characterized in terms of a dialogue. Hence, the title of this presentation: "Constitutional Dialogues Between Courts and Legislatures: Can We Talk?" The dialogue theory is not a new one, but it was new to Canada when introduced by Peter Hogg and Allison Bushell in 1997. ${ }^{2}$ Since then, it has been readily embraced in this country, including by the Supreme Court of Canada itself. ${ }^{3}$ In fact, it was an American, Alexander Bickel, who thirty-five years ago first

This article is a slightly revised version of a paper delivered at the conference on Legislatures and Constitutionalism: The Role of Legislatures in the Constitutional State, Centre for Constitutional Studies, Banff Centre, Banff, Alberta, 2-5 July 2004.

Peter W. Hogg \& Allison A. Bushell, "The Charter Dialogue Between Courts and Legislatures (or Perhaps the Charter of Rights Isn't Such a Bad Thing After All)" (1997) 35 Osgoode Hall Law Journal 75[Hogg \& Bushell]. That metaphor has been criticized in Christopher P. Manfredi \& James B. Kelly, "Six Degrees of Dialogue: A Response to Hogg and Bushell” (1999) 37 Osgoode Hall Law Journal 513; see also Christopher P. Manfredi \& James B. Kelly, "Dialogue, Deference and Restraint: Judicial Independence and Trial Procedures" (2001) 64 Saskatchewan Law Review 323.

See for example, Vriend $v$. Alberta [1998] 1 S.C.R. 493 at 562 67, online: CanLII <http://www.canlii.org/ca/cas/scc/1998/ 1998scc30. html>. postulated a theory of judicial review based on courts and legislatures playing distinct but complementary roles in a dialogue not only between themselves but with society. ${ }^{4}$

The dialogue metaphor is a useful one for comparative and explanatory purposes. However, like all metaphors, it only takes us so far. When one speaks of a dialogue in the context of courts and legislatures, it conjures up an image of two institutions - courts and legislatures - talking to each other where the focal point is the power dynamics between the two. What is missing from this debate about the respective roles of each institution is the underlying purpose of that dialogue. Courts and legislatures exist for a reason - and that reason is to serve the public interest. Both courts and legislatures are accountable to the public interest, though in different ways. Therefore, setting aside abstract theories about the relationship between the two, in the end, it is not about courts and legislatures; it is about the public interest.

It seems to me that the dialogue metaphor in its current form obscures this critical dimension. For my part, a dialogue between the courts and the legislatures must necessarily include the public whom the courts and legislatures both serve. This raises a number of questions. What role does the public interest play in the on-going dialogue between courts and legislatures? Does that role exist within the dialogue or outside it? Who represents the public interest? This public interest dimension to the role of each institution means that, on occasion, disagreements may well arise between courts and legislatures relating to how

\footnotetext{
See Alexander Bickel, The Supreme Court and the Idea of Progress (New York: Harper \& Row, 1970).
} 
that interest might best be served. Resolving these issues may prove difficult if the courts' role in protecting the public interest is not recognized. Take one very practical example - court fees. Ought these be set by government alone or in consultation with the courts?

The debate about the judicial role in a constitutional democracy is not unique to Canada. Similar issues dominate discussions about courts and legislatures in the U.S. However, while Canada and the U.S. have much in common on this subject, there is one key constitutional difference between the two countries. The American Constitution, unlike Canada's, does not contain any limitations on the judicial review power. In Canada, section 1 of the Charter of Rights and Freedoms, ${ }^{5}$ the reasonable limitation exception, and section $33,{ }^{6}$ the notwithstanding clause, afford legislatures a greater opportunity than their American counterparts to save initiatives which might otherwise offend Charter rights. $^{7}$ The American Constitution, by contrast,

Section 1 of the Canadian Charter of Rights and Freedoms, Part I of the Constitution Act, 1982, being Schedule B to the Canada Act 1982 (U.K.), 1982, c. 11, online: CanLII $<$ http://www.canlii.org/ca/consten/const1982.html\#I $>$ [Charter], provides: "The Canadian Charter of Rights and Freedoms guarantees the rights and freedoms set out in it subject only to such reasonable limits prescribed by law as can be demonstrably justified in a free and democratic society." Section 33 of the Charter provides:

(1) Parliament or the legislature of a province may expressly declare in an Act of Parliament or of the legislature, as the case may be, that the Act or a provision thereof shall operate notwithstanding a provision included in section 2 or sections 7 to 15 of this Charter.

(2) An Act or a provision of an Act in respect of which a declaration made under this section is in effect shall have such operation as it would have but for the provision of this Charter referred to in the declaration

(3) A declaration made under subsection (1) shall cease to have effect five years after it comes into force or on such earlier date as may be specified in the declaration.

(4) Parliament or the legislature of a province may re-enact a declaration made under subsection (1).

(5) Subsection (3) applies in respect of a re-enactment made under subsection (4).

Section 1 of the Charter is the primary means through which the courts and legislatures engage in an on-going dialogue. This section allows legislatures to respond to court decisions striking down legislation by shoring up the rationale for impugned contains no comparable clauses. Couple this with judicial supremacy, which has been firmly embedded in the U.S. since Marbury v. Madison, ${ }^{8}$ and add to the mix the difficulties in changing the American Constitution, and it is easy to see why arguments in the U.S. about the legitimacy of the judicial role tend to devolve into arguments about the judges themselves - whom to appoint, how they think, and what they will decide about specific issues, especially contentious social issues.

Canada is also different from the U.S. for another reason. The role of the courts in Canada - as defenders of constitutional rights with full judicial review powers and an arsenal of remedies to match those powers - represents a deliberate and conscious choice made by our elected and accountable governments only twenty-three years ago, when they decided to entrench rights and freedoms in a charter of rights. To enforce Charter rights and protect Canadians, the provincial and federal governments explicitly conferred on the courts the constitutional duty to determine whether challenged state action met Charter standards. This being so, there can be no debate at this time over the legitimacy of the judicial role in defence of constitutional rights. That debate ended in 1982 with legislative action.

The Charter added numerous rights to our Constitution: civil rights, such as freedoms of religion, expression, and association; the right to mobility; the right to counsel; and the right to security of the person. As well, it entrenched human rights, such as equality, linguistic rights, Aboriginal rights, non-derogable gender equality rights, and multiculturalism. And taking a page out of the European Convention for the Protection of Human Rights and Fundamental Freedoms, ${ }^{9}$ the

legislation or re-enacting the challenged legislation in another form. If a law is to be saved under s. 1, it must pursue an important objective, be rationally connected to that objective; impair the rights affected no more than is reasonably necessary to accomplish that objective, and not have a disproportionately severe effect on the persons to whom it applies: R. v. Oakes [1986] 1 S.C.R. 103, online: CanLII <http://www.canlii.org/ $\mathrm{ca} / \mathrm{cas} / \mathrm{scc} / 1986 / 1986 \mathrm{scc} 7 . \mathrm{html}>$. If legislation founders, it is usually in connection with what is often called the "minimal impairment" requirement of Oakes.

8 Marbury v. Madison, 5 U.S. 137 (1803), online: Constitution Society $<$ http://www. constitution.org/ussc/005-137a.htm>.

94 November 1950, 213 U.N.T.S. 222, Eur. T.S. 5. For example, Article 8(2) states: "There shall be no interference by a public authority with the exercise of this right except such as is in 
governments of the day agreed on behalf of we, the people, that these guaranteed rights were subject only to those reasonable limits demonstrably justified in a free and democratic society. This set the bar of permissible state action intruding on those rights relatively high - and deliberately so.

What the Charter has done is make the Court's role as lawmaker more explicit, more pronounced, and more controversial, especially when it comes to interpreting constitutional rights. The reason is that when judges interpret these rights, we determine the extent to which minority rights are entitled to interfere with the majoritarian ones and, thus, the status quo. When the judiciary is called on to consider whether the status quo trenches, for example, on equality rights, it may be required to conclude that it does. The response that sometimes follows when a judge affirms rights for women, racial minorities, the disabled, gays, lesbians, or any other disadvantaged group is that judges are engaged in judicial activism. The criticism seems to be that it should be the legislature and not the courts that determines the scope of rights - and for the courts to do so amounts to impermissible judicial intrusion on legislative supremacy. Indeed, the judge's decision may be challenged, even to the extent of questioning the legitimacy of the judicial role. Those courts that do so overlook a fundamental feature of democracy. As Madam Justice Rosalie Abella has compellingly pointed out, "[t]he most basic of the central concepts we need back in the conversation is that democracy is not - and never was - just about the wishes of the majority. What pumps oxygen no less forcefully through vibrant democratic veins is the protection of rights, through courts, notwithstanding the wishes of the majority." ${ }^{10}$ Thus, in interpreting and enforcing the Charter, the courts are doing precisely what the Canadian Constitution requires - ensuring that the state does not trespass on constitutional rights and freedoms.

accordance with the law and is necessary in a democratic society in the interests of national security, public safety or the economic well-being of the country, for the prevention of disorder or crime, for the protection of health or morals, or for the protection of the rights and freedoms of others."

10 Rosalie Silberman Abella, "The Judicial Role in a Democratic State" (2000) 8:1-3 Canada Watch 8 at 10, online: <www. robarts.yorku.ca/robarts/projects/canada-watch/pdf/cw_8_13.pdf $>$ [emphasis in original].
I now want to return to sections 1 and 33 . As mentioned, the existence of these sections in our constitutional text places Canada in a different position than the U.S. In both countries, certain rights are defined by built-in limitations - for example, the right to be free from unreasonable search and seizure. ${ }^{11}$ It is true that Canada has section 1 and the U.S. does not. But under section 1 of the Charter, the reasonable limit in a free and democratic society exception, it is the courts and courts alone that decide the scope of section 1 .

What makes Canada so distinctive in terms of the relationship between courts and legislatures is section 33 of the Charter, the notwithstanding clause. This legislative override allows legislatures to enact laws that are exempt from certain sections of the Charter. When section 33 is invoked, it is the legislature, and not the courts, that is entitled to define the content of, and limits on, a right and to have the final word. Those rights subject to the legislative override are section 2 (freedoms of religion, expression, peaceful assembly and association), the legal rights in sections 7-14, and equality rights in section 15 . How ever, legislatures cannot override democratic rights (sections 3-5), mobility rights (section 6), language rights (sections 16-23), gender equality rights (section 28 ), and Aboriginal rights (section 35).

How does section 33 operate? When state action is challenged, the usual process involves a two-step analysis: is there a breach of a guaranteed right, and if so, is that breach nevertheless justified under section 1? Section 33 steps past this breach/justification analysis. The notwithstanding clause is premised on the assumption that even if a government is unable to justify a Charter breach to the courts under section 1 , that government will still have the option, if it chooses to invoke section 33 , to try to justify the breach to Canadians. Viewed from this perspective, section 33 was designed as a saving provision under which a government must account to the people, not the

Section 8 of the Charter provides: "Everyone has the right to be secure against unreasonable search or seizure." Amendment IV of the U.S. Constitution provides: "The right of the people to be secure in their persons, houses, papers, and effects, against unreasonable searches and seizures, shall not be violated, and no W arrants shall issue, but upon probable cause, supported by Oath or affirmation, and particularly describing the place to be searched, and the persons or things to be seized." 
courts, for impugned state action. To invoke the notwithstanding clause, a legislature must make an express declaration that it is overriding a particular Charter right. Any such override also contains a sunset provision; the notwithstanding declaration ends after five years unless renewed. ${ }^{12}$

The federal government and the vast majority of provincial governments have never invoked the notwithstanding clause. ${ }^{13}$ This might explain in part the absence of any real debate about the role of section 33 in the dialogue between courts, legislatures - and the public. Yet, it is difficult to engage in a proper dialogue between courts and legislatures if we cannot talk fully about the use of section 33. Why is this so? Why, twenty-plus years into the Charter, is the legitimacy of section 33 challenged by the legal community? ${ }^{14}$ I wish to emphasize that I am not suggesting that the use of section 33 by any legislature should ever become a matter of routine. To the contrary. Both the framework of our constitution and the historical context support the view that the role played by section 33 was intended to be a truly exceptional one - and should continue to be treated as such. Nor am I endorsing the use of section 33 for any specific purpose. Let me take you back to Ottawa, September 1980, and a First Ministers' Conference on the Constitution. The federal

12 The express declaration requirement coupled with the sunset provision impose a further check on the legislative override since the legislature must revisit the issue within the five-year sunset period that typically encompasses an election during that time frame. These points have been compellingly made by Tsvi Kahana, "Understanding the Notwithstanding Mechanism" (2002) 52 University of Toronto Law Journal 221 at 231 [Kahana].

13 Section 33 has been invoked seventeen times by the Québec, Alberta, Saskatchewan, and Yukon legislatures. See Tsvi Kahana, "The Notwithstanding Mechanism and Public Discussion: Lessons from the Ignored Practice of Section 33 of the Charter" (2001) 44 Canadian Public Administration 253 at 257.

14 I do not intend to analyze s. 33 from the perspective of various dialogic theories of judicial review. Many learned articles have been written on this subject exploring those theories, including those based on coordinate construction of the constitution, courts' accountability to society, and courts and legislatures playing distinct but complementary roles. See for example the thorough and thoughtful article by Kent Roach, "Constitutional and Common Law Dialogues Between the Supreme Court and Canadian Legislatures" (2001) 80 Canadian Bar Review 481 [Roach]. Also excluded is any discussion of how the availability of s. 33 might respond to arguments that strong powers of judicial review can lead either to policy distortion, on the theory that legislators focus unduly on whether legislation will survive Charter scrutiny, or to democratic debilitation, on the theory that legislatures abdicate their responsibilities to consider the constitution to the courts. government and the provinces were debating the desirability of repatriating the Canadian Constitution and entrenching a charter of rights and freedoms. The federal government was a strong proponent of entrenchment and full judicial review. A number of provinces feared a wholesale move to the American approach, judicial supremacy, and the consequential loss of Parliamentary supremacy. Therefore, they did what Canadians typically do when faced with a seemingly intractable problem: they compromised. As an aside, section 33 is so characterized by controversy that there is even disagreement on who proposed it. Since this conference is in Alberta, I choose to credit The Honourable Peter Lougheed, former Premier of Alberta. He advises that he proposed the notwithstanding clause to overcome the constitutional divide between those governments supporting judicial supremacy and those supporting Parliamentary supremacy. The rest, as they say, is history. The notwithstanding clause became a key element in the final agreement made on 5 November 1981 to repatriate the Canadian Constitution. ${ }^{15}$ Regardless of the motivation behind the inclusion of section 33, therefore, the notwithstanding clause constitutes a linchpin in the constitutional bargain - one that was intended to be a significant component in the new balance struck by the Charter between courts and legislatures.

With repatriation and entrenchment of the Charter, Canada took a giant step away from our past - which had been characterized by anemic and largely ineffective bills of rights enacted federally and provincially - to a much different future, one in which the judiciary was assigned the primary role as defender of constitutional rights, but governments were entitled in certain cases to invoke a legislative override. Given this historical background, it is somewhat surprising that serious questions are now being raised about the legitimacy of a legislature's invoking section 33 .

\footnotetext{
15 Had the Premiers not agreed to the Charter, the Prime Minister was apparently prepared to proceed with a national referendum on the issue of patriation and the charter of rights. According to polls of the day, the majority of Canadians favoured an entrenched charter of rights. What the vote would have been had the issue been joined on the presence or absence of a legislative override is another issue. See Roy Romanow, John Whyte \& Howard Leeson, Canada ... Notwithstanding The Making of the Constitution 1976-1982 (Toronto: Carswell, 1984) at 205-206, where the authors explore a number of problems that a referendum would have entailed.
} 
To be sure, there were those who, from the start, predicted that the notwithstanding clause would rarely be used. But those predictions were based on the fact that its use would come with a political price, not on any claimed illegitimacy. ${ }^{16}$ And although the clause has never been invoked federally or in the vast majority of provinces, twenty-three years of a new constitution, with limited or no use of section 33, does not a constitutional convention make. ${ }^{17}$

Section 33 represented a compromise between those who favoured judicial supremacy for all rights and those who were equally passionate in defence of Parliamentary sovereignty. It was a compromise on two levels. First, the adoption of the notwithstanding clause made it possible for all governments, other than Québec, to agree to the resulting constitutional package. Second, the section 33 override represented a compromise between the two extremes in the debate surrounding entrenchment of rights and judicial review. As Paul Weiler explained, the override resulted in "a compromise, between the British version of full-fledged parliamentary sovereignty and the American version of full-fledged judicial authority over constitutional matters." 18 Consequently, neither institution was given the final say in all cases. The courts do not have the final say on all rights because of section 33 ; and the legislatures do not have the final say because the section 33 override does not apply to all rights and, in any event, it does not last forever.

However, as sometimes happens when people compromise on principles, the principles - and conflicts arising from the clash of principles - do not necessarily go away. While a compromise

16 Prior to his appointment to the Supreme Court of Canada, Gerard LaForest predicted that s. 33 would rarely be used given the political unpopularity of doing so: Gerard V. LaForest, "The Canadian Charter of Rights and Freedoms: An Overview" (1983) 61 Canadian Bar Review 19 at 26. His thesis was that the courts would generally defer to legislation re-enacted in another form than the one initially rejected by the courts.

17 The fact that s. 33 has rarely been used does not mean it cannot be used when and if a legislature chooses to do so. A similar argument that the non-use of a right constituted desuetude was made and dismissed by the Supreme Court of Canada in connection with the power of the Governor-General to disallow provincial Acts: Reference re Powers of Disallowance and Reservation [1938] S.C.R. 71.

18 Paul C. Weiler, "Of Judges and Rights, or Should Canada Have a Constitutional Bill of Rights?" (1980) Dalhousie Review 205 at 232 . represents an attempt to bridge a gap between differences, it does not always mean that a true consensus has been reached. Witness the original argument about judicial supremacy versus Parliamentary sovereignty now being played out in a different way as strong differences have arisen concerning the legitimacy of a legislature's invoking section 33 .

Let me now turn to those differences. First, some see this issue in terms of fundamental rights. In their view, all rights are inalienable. The content and shape of those rights exist independent of judicial definition. Thus, any restriction on such rights would be an affront to human dignity and the moral underpinnings of our democracy. Hence, no legislature should ever use section 33 to override inalienable rights. Others disagree, pointing out that characterizing all rights as inalienable is not accurate. Some rights are inalienable, but some are not. A number of Charter rights are open-ended and deliberately so. Hence, the use of indeterminate and general language in several sections. Take section 7 for example. ${ }^{19}$ This broad right is not susceptible to precise and exhaustive definition. With this section and others, the courts therefore play a significant role in defining the content and scope of the right. This being so, those who support the possible use of section 33 contend that if a legislature should determine that a court has gone too far in settling the content of a right - and the legislature is willing to pay the political price involved in invoking the legislative override and restricting the content of that right - then there is nothing illegitimate about its doing so. In other words, where there is no unanimity on what is included in a right, the margin for legislative involvement in defining the limits of that right is more defensible. It must be conceded that if one stepped back twenty-three years and asked lawyers, the academic community, the governments, and the public how the courts would

\footnotetext{
19 Section 7 provides: "Everyone has the right to life, liberty and security of the person and the right not to be deprived thereof except in accordance with the principles of fundamental justice." However, there is no unanimity on what is protected under s. 7. The recent decision of the Supreme Court of Canada, which addressed whether the Québec government had breached Charter rights by not extending to young unemployed individuals the same benefits as extended to older citizens, illustrates this point Gosselin v. Québec (Attorney General) [2002] 4 S.C.R. 429, 2002 SCC 84, online: CanLII <http:// www.canlii.org/ca/cas/scc/2002/2002scc84.html>.
} 
define certain legal rights under the Charter, few would have predicted where we are today.

Second, some see the conflict in the event of a Charter breach as one involving the individual versus the state only. On this view of Charter breaches, there is only one right at stake - and the state is seeking to deprive a person of that right. They argue that once the courts have determined that state action breaches the Charter, the state should not use another instrument of state action, section 33 , to override the breach. In their view, section 33, while legal, lacks legitimacy as a legislative option. The state should instead defer to the courts. Those who defend the legitimacy of section 33 point out that sometimes rights conflict, and state action is often motivated not by a pursuit of the state's own social goals but rather by a felt need to protect countervailing rights. Take, for example, Parliament's efforts to protect the medical records of sexual assault complainants by curtailing fishing expeditions by defence counsel. ${ }^{20}$

Certainly, the Supreme Court of Canada has made it clear that there is no hierarchy of rights under the Charter. ${ }^{21}$ This statement constitutes a strong recognition that there are competing rights and that when rights collide, a court must balance and weigh competing rights and make a value judgment about which right will prevail, in what circumstances, and to what extent. Indeed, a preference for one right over another may not be shared, even by all judges on the Supreme Court of Canada itself. ${ }^{22}$ Accordingly, to those who see

$20 \quad$ Parliament passed the first rape shield legislation in 1982. That legislation was later declared unconstitutional in $R$. v. Seaboyer R. v. Gayme [1991] 2 S.C.R. 577, online: CanLII <http://www. canlii.org/ca/cas/scc/1991/1991scc68.html>. Parliament then responded to the Supreme Court decision with s. 276 of the Canadian Criminal Code, R.S.C. 1985, c. C-46, online: CanLII $<$ http://www.canlii.org/ca/sta/c-46/>. That legislation has since been upheld in R. v. Darrach [2000] 2 S.C.R. 443, 2000 SCC 46, online: CanLII <http://www.canlii.org/ca/cas/scc/ 2000/2000scc46.html>.

21 Dagenais v. Canadian Broadcasting Corp. [1994] 3 S.C.R. 835 at 877 , online: CanLII <http://www.canlii.org/ca/cas/scc/ 1994/1994scc102.html>

22 That can be seen by the numerous cases in which the Supreme Court has split 5:4 on Charter issues. See, for example, Rodriguez v. British Columbia (Attorney General) [1993] 3 S.C.R. 519, online: CanLII <http://www.canlii.org/ca/cas/scc/ 1993/1993scc101.html>; R. v. O'Connor [1995] 4 S.C.R. 411 , online: CanLII <http://www.canlii.org/ca/cas/scc/1995/ 1995scc103.html>; RJR-MacDonald Inc. v. Canada (Attorney General) [1995] 3 S.C.R. 199, online: CanLII <http://www. canlii.org/ca/cas/scc/1995/1995scc72.html>;R.v.Egan [1995] section 33 as a useful tool, sometimes the balance chosen may not be sufficiently responsive to the legitimate needs of Canadian society. In this event, in their view, it is not unreasonable for a legislature to elect to place a different weight on certain rights than a court has chosen to do. They argue that when section 33 is used to reverse judicial interpretations of some rights - in what may be highly contested 5:4 decisions of the Supreme Court of Canada - legislatures are not eroding rights, but rather righting the balance.

Third, those opposed to the legislative override view courts as the guardian of fundamental rights and freedoms. Only the courts have the institutional characteristic required, namely independence, to defend individuals and minorities against improper actions. This is why the courts, and not the legislatures, must have the final say on protected rights. Those in support of the possible use of section 33 contend that this approach to judicial decision-making overlooks the fact that in many cases of conflicting rights there is no absolute right or wrong answer. What makes an answer a final one is that five judges on the Supreme Court of Canada decided a case that way, even if four judges on that Court reached a contrary conclusion, choosing, for example, to place rights of other vulnerable groups on the scale. In their view, it is difficult to contend that a decision of four judges on the Supreme Court is an unreasonable one. ${ }^{23}$ As one academic has said, "[t]he correct understanding of judicial finality is neither that courts are final because they are infallible, nor that they are infallible because they are final, but, instead, that they are final even though they are fallible." ${ }^{24}$ Further, since the dissents of today may well be the majority decisions of tomorrow, those who support the use of section 33 contend that legislative intervention in support of a reasoned and principled dissent is

2 S.C.R. 513, online: CanLII <http://www.canlii.org/ca/cas/ scc/1995/1995scc49.html> R. v. Rockey [1996] 3 S.C.R. 829, online: CanLII <http://www.canlii.org/ca/cas/scc/1996/ 1996scc111.html >; R. v. Feeney [1997] 2 S.C.R. 13, online: CanLII <http://www.canlii.org/ca/cas/scc/1997/1997scc47. html>; R. v. Hydro-Québec [1997] 3 S.C.R. 213, online: $<$ http://www.canlii.org/ca/cas/scc/1997/1997scc80.html >; and R. v. Corbiere [1999] 2 S.C.R. 203 online: CanLII <http:// www.canlii.org/ca/cas/scc/1999/1999scc29. html>.

23 In fact, there may be cases in which, if one added up all the votes on the courts below, a majority of judges supported the minority interpretation.

24 Kahana, supra note 12 at 243 [emphasis in original]. 
quite appropriate. On this thinking, if the dissent can inform future majority decisions, then why not a legislative decision at an earlier stage? And if this cannot be achieved through reply legislation saved under section 1, then why not the section 33 override? Or to put it the way that two academics have done, "If Parliament cannot side with the minority in a closely contested judicial disagreement, then the promise of interinstitutional 'dialogue' amounts to very little." 25

Fourth, those who dispute the legitimacy of section 33 tend to assume that courts will always be protecting rights and legislatures will always be breaching them. Others suggest that this is neither a respectful premise nor one that is historically correct. There is no doubt that courts can be expansive in defence of rights or restrictive in curtailing rights. And governments can be the same. The Lochner ${ }^{26}$ era in the U.S. - during which the courts were a barrier to progressive government legislation, striking it down as unconstitutional - is an example of that ${ }^{27}$ Unable to rely on a legislative override such as section 33, the U.S. President instead proposed a "court packing" bill. ${ }^{28}$

Fifth, a strong argument against the use of section 33 is that governments already have a sufficient opportunity to protect their legislative agendas under section 1 . In other words, why is section 33 necessary when section 1 is available to save legislation? Furthermore, those who question the use of section 33 point out that most legislation struck down by the courts has been reenacted in some form and ultimately upheld by the courts under section 1. In other words, section 1, in both content and scope is, and should continue to be, the primary vehicle for dialogue between courts and legislatures. There can be little doubt

25 Dennis Baker \& Rainer Knopff, "Minority Retort: A Parliamentary Power to Resolve Judicial Disagreement in Close Cases" (2002) 21 Windsor Yearbook of Access to Justice 347 at 354 .

26 Lochner v. New York, (1905) 198 U.S. 45, online: Constitution Society <http://www.constitution.org/ussc/198-045b.htm>, was a case in which the state legislature's efforts to limit the hours of employment was found to be an arbitrary interference with the freedom to contract guaranteed by the United States Constitution. The United States Supreme Court declined to find this interference to be a valid exercise of the police power to protect public health, safety, morals, or general welfare.

27 Hogg \& Bushell, supra note 2 at 78.

28 Peter H.Russell, "Standing Up For Notwithstanding" (1991) 29 Alberta Law Review 293 at 298. that the existence of section 1 weighs very heavily in favour of restricting any use of the section 33 override to exceptional cases. Those who support the legitimacy of section 33 contend that this safety valve is required if repeated legislative efforts should continue to be struck down by the courts on the grounds that the means chosen to achieve the objective are not the least restrictive regardless of how compelling and consistent with the public interest that objective might be. Further, they point out that the section 1 analysis rests on what is demonstrably justified in a free and democratic society and that there will be a range of legislative choices since not all democracies have exactly the same laws. They also stress that an analysis under section 1 of the Charter does not typically focus on a comparative law analysis of other democratic countries.

More fundamentally, though, more than one academic has argued that if section 33 is not an option available to legislatures, courts might feel more constrained in their judicial review role and more inclined to defer to legislatures under section 1 when reply legislation comes back before a court. This would in turn lead to an unnecessarily restrictive interpretation of rights, thereby impeding the development of rights. On this theory, therefore, the availability of the section 33 override will, on balance, be more useful in promoting rights than restricting rights or, at the very least, will promote public involvement in our democratic institutions. ${ }^{29}$

Sixth, those who assert that judicial supremacy must prevail presume that the courts' pronouncements on guaranteed Charter rights are correct. Those who advocate the use of section 33 disagree; in their view, the process may not be as pure as many might believe. In other words, in their view, courts do not always get it right. For example, in 1928 the Supreme Court of Canada concluded in Edwards v. Canada (Attorney General) $^{30}$ that women were not persons for

29 For examples of those who have argued that s. 33 makes courts bolder, see Lorraine Eisenstat Weinrib, "Canada's Constitutional Revolution: From Legislative to Constitutional State" (1999) 33 Israel Law Review 13 at 49; Roach, supra note 14 at 530 .

30 Reference as to the meaning of the word "Persons" in section 24 of the British North America Act, 1867 [1928] S.C.R. 276, online: Canadian Human Rights Commission $<$ http://www.chrc-ccdp.ca/en/brow seSubjects/edwardsscc. asp $>$. 
purposes of appointment to the Senate. It took an appeal to what was then the final court of appeal for Canada, the Privy Council, to reverse that decision in $1930 .{ }^{31}$ Further, the fact that courts of appeal in Canada, including the Supreme Court of Canada, reserve the right to overrule binding precedent is itself recognition that, sometimes, court decisions may warrant reversal. Accordingly, those who consider section 33 as a legitimate legislative option ask this rhetorical question: If a court can change its mind, why can't a legislature use section 33 to correct a court decision in a more timely manner?

No matter what view one takes of the original intention behind section 33, whether to correct judicial errors, or to protect legislative initiatives, or to provide a safety net where the legislature simply disagrees with a judicial decision, one point is clear. Section 33 was intended to be an exceptional tool only. It will also be evident that the legitimacy of the use of section 33 will be less likely to be challenged where legislatures are expanding and not restricting rights, or where legislatures are changing the balance between otherwise-conflicting rights.

In all cases, the burden on the legislature to convince the public why it must interfere with what are otherwise protected constitutional rights will be a very heavy one. How will the public interest be protected, and what public consultation/hearings/committee process will be undertaken before a legislature takes this step? After all, one of the reasons for the section 33 process is to ensure that legislators make decisions from positions of full knowledge and understanding of the consequences of the steps they will be taking. As the Honourable Peter Lougheed has said: ${ }^{32}$

The purpose of the override is to provide an opportunity for the responsible and accountable public discussion of rights issues, and this might be undermined if legislators are free to use the override without open discussion and deliberation of the specifics of its use.
The Charter is only twenty-three years old and the equality provisions have been in force for only twenty years. We are still at an early stage in the Charter's evolution and the rights and freedoms guaranteed under it. As we continue to talk, and come to recognize the extent to which court decisions are sometimes based on a weighing and balancing of competing rights, we may better understand the conflicts and compromises involved in shaping the scope of those rights and, in turn, the respective roles of the courts and legislatures in maintaining an open, constructive and continuous dialogue in the public interest.

\section{The Honourable Catherine A. Fraser}

Chief Justice

Court of Appeal of Alberta
Edwards v. Canada (A.G.), [1930] A.C. 124 (P.C.).

32 Peter Lougheed, "Why A Notwithstanding Clause?" (1998) 6 Points of View 1 at 16 . 